\title{
Professional Development and Educational Policy: A Comparison of Two Important Fields in Education
}

\author{
Linda E. Martin \\ Ball State University \\ Sherry Kragler \\ University of South Florida (retired) \\ Denise Frazier \\ Purdue University Northwest
}

\begin{abstract}
The purpose of this paper is to compare two fields of research related to school reform: professional development and educational policy. A content analysis of the literature in both fields revealed two areas where they align (i.e., a focus on teachers' professional development and the idea that change takes time) as well as two areas where there are differences (i.e., theoretical grounding of each field and planning for teachers' learning). Considerations for successful school reform are suggested.
\end{abstract}

Keywords: professional development, educational policy, impact on school reform, teaching and learning

\section{Introduction}

School reform is not new to our educational system (Allington, 2009; Shannon, Edmondson, Ortega, Pitcher, \& Robbins, 2009). Historically, reform movements (local, state, and federal) have, in some way, impacted schools for different reasons (e.g., religion, materials and textbooks, how one learns, and what is learned). For the purpose of this article, the researchers focused on the most recent reform movements which began with the Elementary and Secondary Education Act (ESEA) of 1965 (Edmondson, 2004). At that time, a more social perspective of American education emerged. From that stance, several issues were the focus of reform, including civil rights, achievement test scores, international rating, and the gap between low- and middle-income students' overall achievement (Shannon et al., 2009; West \& Peterson, 2003). A Nation at Risk (U.S. Department of Education, 1983) provided the impetus for reforms in the 1980s, with a focus on competition abroad, increased parental involvement, and increased teacher training. In 2000, the ESEA was again given the authority to develop incentives for teachers when their students performed well on state testing. The federal mandates from the legislation in No Child Left Behind (NCLB) were meant to encourage closer relationships among agencies at all levels, federal, state, and local (Schmidt, 2008), but instead, its prescriptive federal requirements did not align with the needs of many schools and educators (Long, 2014). As a result, the ESEA was revised as the Every Student Succeeds Act (2015), which allows for more state input in providing quality education for all children. Thus, leadership in states and school districts are developing policies to meet the revised federal mandates that hopefully bring about school reform and increase student achievement. 
For several years, the researchers have been involved with various professional development initiatives that focused on the improvement of classroom instruction and have observed the impact of mandated policies on teachers' instruction. Policies often are developed from legislation such as NCLB, and within those initiatives, the federal government has advocated the importance of teachers' professional development. However, in many cases, the professional development suggested by policy initiatives is sometimes generic (Marrongelle, Sztajn, \& Smith, 2013) or is narrowly defined by these initiatives and prescriptive in content (Long, 2014). As a result, most schools have remained basically unchanged in the way that instruction is delivered (Cummins, 2007; Kragler, Martin, \& Kroeger, 2008; Wolk, 2010). To better understand this phenomenon, the researchers compared the literature in the fields of professional development and educational policy.

To begin, the researchers examined articles and texts no older than the year 2000 pertaining to the topics of educational policy and teacher professional development. The result of this initial search elicited approximately 375 sources that included professional as well as practical articles, chapters, and so forth. As they were collected, the researchers read the different sources individually and then met bimonthly to discuss the findings. As a result, the focus of the search for sources in both fields was narrowed to include (a) well-known scholars, (b) research studies, and (c) scholarly reports collected across data bases (e.g., ERIC, Proquest, JSTOR, Card Catalog), which led to 72 pertinent resources for professional development and 64 for educational policy. This was a 1-year process.

Once the initial reading took place, the researchers individually read the pertinent data for a second time, and memos were made to note general thoughts about the information in the sources. For example, various sources from both professional development and educational policy noted teacher change takes time. The researchers then met to discuss these initial memos. Afterwards, the researchers individually began to list and cluster the memos into categories. Again, the researchers met to discuss and to validate the codes and categories as well as label the categories. The procedure of individually reading to identify and to code patterns for each source and then afterwards discuss the findings at each step assured the validity of the analysis (Creswell, 2003; Krippendorff, 2004). With bimonthly meetings, eventually themes were identified that supported the categories and revealed how research that focuses on teacher professional development and educational policy align and how they differ.

To illustrate, as the data sources were read over time, one common topic was the importance of teacher quality. Both fields of research noted that effective instruction led to improved student outcome and continued teacher professional development was important. The topic of teacher quality was coded. Further, both fields examined the complexity of school reform and the various reasons that may inhibit successful reform movements. This became another coded area with subtopics. Eventually, teacher quality and the complexity of school change became themes that align to both teacher professional development and educational policy.

In conclusion, the content analysis revealed two prevalent patterns in the literature where the fields of professional development and educational policy align and two patterns where there are some differences. The findings of this research may contribute to a greater understanding of each area of study and how they can be used to more successfully guide the professional development of teachers. The results are reported below.

\section{Alignment of the Fields}

\section{Focus on the Quality of Teachers}

Both fields of research, educational policy and professional development, focus on the importance of quality instruction in the schools (Rose, 2010). Because schools with effective teachers produce better learning outcomes from their students (Darling-Hammond, 2010; Dillon, O'Brien, Sato, \& Kelly, 
2011; Hill, 2009; Rose, 2010), professional activities that help teachers make instructional changes seem to be at the heart of the discussions in both fields. These professional activities can be delivered in various ways, such as web-based interactive seminars that are most commonly used in today's schools for meetings, remote training, and workshops. Further, teachers can attend conferences, take university courses, work with consultants, or participate in special programs that enhance their learning, such as the National Writing Project.

Whatever method of professional development is delivered, teachers are the focus and have been for some time (Hargreaves, 2014; Lieberman \& Miller, 2014). This has been the direct result of policy that advocates a need for schools and ultimately teachers to be accountable and to implement instruction that will lead to students' success (Hochberg \& Desimone, 2010). Consequently, researchers began to examine the impact of professional development for teachers on student achievement (Wayne, Yoon, Zhu, Cronen, \& Garet, 2008), as well as how teachers make instructional changes (Garet, Porter, Desimone, Birman, \& Yoon (2001). Hochberg and Desimone (2010) argued that the ability of professional development to succeed as a mechanism for improving student achievement may depend, in a large part, on its ability to bridge divides among teachers' knowledge, beliefs, and practices. Garet and colleagues (2001) found three structural features of professional development: (a) the form in which professional development is delivered, (b) the duration of the professional development, and (c) the type of collaborative participation that takes place. As one can see, teachers do appear to be the objects of professional development policies, and they also appear to be the method for change desired by policy makers (Valencia \& Wixson, 2004).

\section{Change Is Complex and Takes Time}

Often, the pressure to raise test scores leads administrators to schedule a variety of professional development activities for teachers. Generally, the teachers are to attend the activities then implement what has been introduced into their teaching routines. However, research in the professional development and educational policy fields indicate that school reform is complex and takes time, generally many years for new teaching behaviors to become a permanent part of a teacher's routines (Evans, Thornton, \& Usinger, 2012; Guskey \& Yoon, 2009; Rose, 2010; Wilkinson \& Son, 2011). Taylor, Pearson, Peterson, and Rodriguez (2005) conducted a study to examine teachers' success in implementing reform that focused on research-based reading instructional practices in 13 high-poverty schools across five different states. Eight of the schools were in their second year of a professional development project, and five were in their first year. They concluded that effective school improvement was difficult to achieve because of all that has to be considered, three of which are the school culture, the teachers, and the professional development programs that are implemented.

\section{School Culture}

The school context plays a large role in the learning of all its inhabitants. Sarason (2004) emphasized the role of the school culture in creating places of learning for students and staff. In order to have successful school reform, one has to look at the values, beliefs, and norms in each school. Professional development programs that work in one context may not work in another context (Murphy, 2013). Teachers who teach math at the high-school level may need different types of professional development activities than teachers who work at the elementary level. Teachers who work at schools that have predominately middle to higher income families will need different types of professional development than teachers who work at schools where there is a large proportion of lower income families or students whose families are currently homeless.

As a result, educators may need different learning opportunities based on where and what they teach. Putnam and Borko (2000) contended a situative perspective can provide a critical basis for designing and implementing programs that facilitate student and teacher learning and can find 
"context-based solutions" (Woodside-Jiron \& Gehsmann, 2009, p. 66). Without looking at the interconnections of the teachers and school culture, no real change can occur (Firestone \& Mangin, 2014; Sarason, 2004).

To implement new initiatives, schools need well-established leadership to build a positive culture for all of the inhabitants (Bryk, Sebring, Allensworth, Luppescu, \& Easton, 2010; Leathwood, Harris, \& Hopkins, 2008). School leadership should also support a plan for change with a strong theoretical frame of how to proceed. Evans and colleagues (2012) asserted school leadership must "engage in professional development to enhance the critical skills necessary to orchestrate effective change" (p. 169). School leaders can establish this by using strategies, such as team building, collaboration, and the use of inquiry.

\section{Teachers}

As with other professionals, there is a range of abilities and professional knowledge. Not all teachers are at the same stage of development at the same time. Snow, Griffin, and Burns (2005) described five levels of increasing teacher knowledge. The levels begin with the teachers' awareness of the foundation of disciplinary knowledge needed for their success and lead to the teachers' ability to analyze programs and choose methods that work best with their students. Professional learning programs should focus on the "expectation of and the skills required for continuous learning" (p. 212). Thus, each level helps set the stage for the next level. In this format, professional learning is instructive (Long, 2011) as teachers develop in-depth and relevant knowledge that they can use with different students and in contexts (Snow et al., 2005).

Often, teachers' understanding of a policy will not align with its intent (Spillane, Reiser, \& Reimer, 2002). Spillane et al. asserted that even if teachers correctly understand the intent of a new policy, they may lack the knowledge, beliefs, and experience to implement it, or they may lack the necessary skills and resources to put their understanding of a new policy into practice. As Hargreaves (1995) stated, "change must come, in part, from within. This situation makes the achievement of fundamental changes in teaching practices difficult, because a teacher's existing conceptions of learning and of subject matter can be quite resistance to change" (p. 60). Coburn (2001) considered this behavior to be a form of gate keeping, so teachers can preserve their image, but yet not make any drastic changes to their daily routines.

The implementation of suggested changes can also be impacted by teachers' self-efficacy and their collective perspectives are shaped by the interactive relationship between the learners, the learners' behavior, and the contexts in which they are learning (Kragler et al., 2008). Therefore, teachers have individual professional development goals based on the success of their instructional practices but they may also act collectively to support shared goals (Bandura, 1977). Even within a collective effort, teachers may take different avenues to learn. In a study of teachers' personal perceptions and collective perceptions during a long-term professional development mandated through a large grant in two urban schools in a large metropolitan area of the Midwest, Kragler et al. (2008) found the teachers felt they and their colleagues had the skills to teach their at-risk students. While the teachers enjoyed the new materials they received through the grant, they were not receptive to instructional changes that were expected. They generally felt any issues were due to the fact their students did not come to school ready to learn.

Finally, another factor that may contribute to the complexity of the teachers' ability to make instructional changes is seen in the daily routines that encompass teachers' lives in their workplace (Fullan, 2000; Knapp, Bamburg, Ferguson, \& Hill, 1998; Knight, 2009). Beyond attending to the individual needs of their students and their families, there are stacks of papers to grade and lessons to develop, as well as other tasks that they encounter during a work day, for example, be on duty 
(hall, recess, lunchroom), attend meetings, and complete reports. Finding effective ways for teachers to do that is not easy, especially considering that they are already multitasking (Grady, Helbling, \& Lubeck, 2008; McMullen, 2006).

\section{Professional Development}

Glickman (1990) stated educators and others cannot "pretend not to know what we know" (p. 4), and over the years, the researchers have learned a great deal about professional development and learning of teachers. In a report on the status of professional learning of teachers, DarlingHammond, Wei, Andree, Richardson, and Orphanos (2009) found many attributes of professional development were in place, such as teachers being involved in professional development of some type and teachers having the opportunity to be engaged in a wide variety of activities. There was also a focus on the development of subject matter content. However, there were some issues in what they found. To begin, teachers were disappointed in many of their activities. Also, there was little support for teacher collaboration to discuss curriculum, policies, or other decisions regarding their schools. The authors concluded that there is a

growing body of research on effective professional development for a new paradigm of teacher professional learning, one based on evidence about the kinds of experiences that appear to build teacher capacity and catalyze transformation in teaching practice resulting in improved student outcomes. (p. 27)

There is information about the attributes of effective professional learning (Desimone, 2011), and some attributes are instructiveness, substantiveness, and reflectiveness (Desimone, 2011; Donnelly et al., 2005; Long, 2011). These need to be considered when planning professional development. Without these, professional development will not be planned or implemented well, and little school improvement will occur (Guskey \& Yoon, 2009).

In conclusion, there are two overlapping themes in these fields. First, both professional development and education policy focus on the quality of teachers and helping teachers become more proficient in their respective fields. Both fields align teacher quality as a mechanism to increase student learning. Second, both fields agree that school reform is very complex and takes time. It is not something that happens in 1 year but can take 5 or more years to fully implement new initiatives. In the next section, differences in how scholars in the fields of teacher professional development and educational policy approach school reform are discussed.

\section{Discord: Differences in the Fields}

The advocates of both professional development and policy research assert that teacher and school needs have to be met. The content analyses indicated two major ways these fields differ. One is the theoretical grounding of each field, and the other is the actual development of the professional development activities.

\section{Theoretical Grounding}

\section{Professional Development}

While there are several learning theories that can ground and support professional development, two predominant theories are adult learning theory and transformational learning theory, which are both based on a constructivist theoretical frame. Adult learning theory recognizes learning is a personal, developmental, and constructive process (Desimone, 2011; Knowles, 1970; Merriam, 2001; Vygotsky, 1978). Adults bring a variety of life experiences to learning. Consequently, they may approach learning differently, because they are at various stages of their development (Knowles, 1970; Merriam, 2001; Mezirow, 1994). Knowles (1980) perceived adult learners/educators as change 
agents; their role is to encourage, to consult, and to become a resource to others. He believed adults should have ownership of their learning, both by asking their own questions but also searching for the answers to their questions.

Transformational learning, on the other hand, describes how teachers develop professionally over time. Mezirow (1994) identified a series of steps that one goes through to internalize new ideas and ultimately change. At first, there is disorientation, which is followed by guilt and the shared recognition of one's struggles with others to change. Once these struggles have been shared, one begins to examine the issues and options to be taken to change and assess how to make it work. A preliminary plan is then implemented as one begins to develop new knowledge and skills. With reflective practice over time and encouragement, competence, and self-confidence transforms one's life and routines. Mezirow (2003) believed that the struggle to transform one's learning and break old habits and perspectives must be reflective, problem solving, and collaborative to make lasting changes.

This is not an easy task for a teacher who has taught a specific way for a long time. One good example of a teacher's transformation over time is Jack (pseudonym), a first-grade teacher in a rural Midwest school, as he began the implementation of the writing workshop over 13 years ago. In his journey to learn about how children think and learn about writing, he also discovered ways to guide their success and change his instruction. As his confidence developed, so did his need to learn. This led to National Board Certification, and his involvement in the National Writing Project. This example shows that adult learning theory and the constructivist theory are both nested within the context of the transformation. Engagement in meaningful professional development over time allows teachers to transform their beliefs about instruction, which affects how they teach.

In essence, these theories describe the different issues that need to be considered for teachers' professional learning over the course of a career. As professional educators, their obvious focus is their students' learning by way of effective instruction. This can only be obtained through constant reflection, collaboration, and problem solving to find success. In the process, they also grow and change professionally over a lifetime of new experiences.

\section{Educational Policy}

Educational policy research is grounded in institutional theory and sensemaking theory. Coburn (2001) described institutional theory as a "cultural" approach to reform, meaning that attempts are made to examine the multilevel needs of a school faculty and the children who are taught. Institutional theory focuses on the "messages" sent from a school or schools. Thus, the school as a whole is the focus rather than individual teachers' needs. Educational policy theorists believe "messages" or the data (scores and classroom practices) gathered from a school environment should be examined for patterns or norms in classrooms. Dissatisfaction with teachers' classroom instruction can evolve into formal policy to reform the educational environment. For example, the results of state testing can initiate those in charge to shape teacher professional development that not only focuses on instructional programs but the texts and materials as well (Coburn, 2001, 2006). Institutional reform can be implemented at the federal, the state, the district, and local levels (Knapp et al., 1998; Valencia \& Wixson, 2004).

Sensemaking theory, on the other hand, describes how teachers within their school environment interpret and adapt messages from outside the school that include policies (Coburn, 2001). This usually comes in the form of a new mandate or policy that would be implemented in schools. Weick, Sutcliffe, and Obstfeld (2005) described several characteristics of sensemaking. Initially, the message appears to be disorganized and chaotic when introduced to the teachers. Over time, sense (organization) is made of the message according to how the teachers collectively interpret it to fit their school and classrooms. Coburn (2001) described schools as microcultural environments in which teachers, staff, and children all live each day. Within that frame, teachers' and principals' 
beliefs of learning and how that impacts instructional routines makes each school a unique place. Weick and colleagues (2005) also described sensemaking as social, systemic, and actually organized through discussions over time. Considering individual teachers may react in different ways, dialogue over time focused on the new message is hoped to build consensus.

A principal of a rural school (kindergarten to Grade 5) was concerned about the students' low writing scores on a statewide mandated test. Working with a consultant and examining the different approaches to writing instruction, the principal decided the teachers needed to implement the writing workshop. To begin, the teachers attended various professional development sessions over 10 weeks during the fall semester that included and described the various components of an effective writing workshop (Ray \& Cleaveland, 2004). Afterwards, they were expected to fully implement the writing workshop within their classrooms. Over time, the consultant observed the teachers' attempts to make sense of teaching the writing process within a workshop frame. Some who were already using the writing process easily implemented this new method of instruction; others, however, struggled to make sense of this approach. These teachers implemented a simple aspect of the writing workshop (e.g., a writing center or author chair), but their instruction did not change. Obviously, more time should have been allowed for the teachers to reflect on what they knew about the writing process and how to implement a new and different program within their school. Once initiated, they needed continued support with reflection and collaboration in order to be successful.

In summary, institutional theory focuses on the outcome of information sent from the whole school environment (e.g., test scores). For example, if student test scores are low, new policies are implemented to change the classroom instruction and to lead increased test scores, whereas sensemaking theory pertains to how teachers and administrators address any new policy in their school. They work collaboratively to problem solve and to develop strategies to support student learning.

\section{Planning for Teachers' Learning}

\section{Professional Development}

Knowledge of how educators learn and what should take place for their professional development has evolved over decades, from the days of inservice workshops that were popular in the " 50 s and '60s through the staff development days to the current view of ongoing professional learning of teachers. The result of this has been the evolution of a new way to conceptualize teachers' learning as an ongoing process (Sarason, 2004). The emphasis is on the continued growth of teachers and school leaders (Katzenmeyer \& Moller, 2001). Professional learning within a community of learners is one way to envision ongoing professional learning (Lieberman \& Miller, 2014). Teachers are viewed as professionals who can engage in thoughtful meaningful dialogue about the needs of their school and the school community, their individual professional learning, and the learning of the students in their classrooms. Time is allotted for them to reflect on their learning and to collaborate with their peers and other professionals (inside and outside the school) to solve problems that will enhance their instruction and promote student success. In this manner, teachers create an inquirybased learning environment that focuses on the school, their professional learning needs, as well as their students' learning (Jacobs \& Yendol-Hoppey, 2014).

\section{Educational Policy}

Historically, federal mandates to change the way that students are taught have been based on scores (Lieberman \& Miller, 2014; Long, 2014). Professional development for teachers is commonly derived by directives from the district or state and is based on economics and competition. Examples of this have been the emphasis on science and math during the Sputnik era; the NCLB era; the Common Core standards (Long, 2014); the new Science, Technology, Engineers and Mathematic Federal Initiative (Executive Office of the President, 2013); and the Every Student Succeeds Act (U.S. Department of Education, 2015). However, even though these mandates have called for professional 
development of teachers, many of these programs are of short nature and are not aligned with what is known about effective professional development (Long, 2014). In many cases, districts have mandated the use of certain programs and assessments without considering if these are appropriate for their students (Valli, Croninger, \& Buese, 2012). In fact, materials that are aligned with the Common Core are being developed that all teachers can use (Rothman, 2012-2013) regardless of the school context.

Often, the focus of the professional development is broad and supports beliefs and values of those who are in charge rather than on relevant research (Coburn, 2006). For example, because the student scores were especially low in one urban school, it was decided by the school leadership (local and district levels) that a more explicit phonics approach to instruction was needed, especially in the primary grades (kindergarten through third grade). Therefore, a scripted reading program that had a strong phonics component was mandated to supplement what they felt was missing. A consultant was brought in to make sure the teachers were following the scripted lessons from the texts.

It is common for schools to establish multiple mandated professional development topics making it difficult for teachers to focus on the most relevant issues (Kragler et al., 2008) in their classrooms. One school the researchers encountered had teachers attending professional development to implement new math and reading programs, develop a program to promote good health (such as drug prevention), and examine how the brain functions to help one learn. As a result, there was an overload of information, and the teachers were not engaged in the learning process (Scot, Callahan, \& Urquhart, 2009).

\section{Translating Education Policy Into Practice}

As has been revealed, the process of translating education policy into practice is complex and involves many layers of initiatives at the state and local levels that regulate what is important in a policy and how it will be accomplished (Cohen, McCabe, Michelli, \& Pickeral, 2009; Honig, 2006; McLaughlin, 2006). While it has been found, that in general, "policies do not make change" (Jaquith, 2014, p. 89), the federal government continues to legislate policy to improve instruction in schools. However, the implementation of the policy is dependent on state funding and regulation. Each state determines how to implement and to fund each particular directive. This can lead to state-by-state variance in the implementation and success of any mandated policy, and therefore, there is no straight path from policy to professional development to instructional implementation to student success (Jaquith, 2014).

Marrongelle and colleagues (2013) suggested that as state education leaders move from policy to the implementation of policy initiatives and regulations to professional development opportunities, it is incumbent to remember what works and what doesn't work. They described studies of effective, successful professional development that led to increased student learning, as well as research that did not lead to increased student learning. Only rich descriptions of the professional development environment of these studies will lead to an understanding of what needs to be considered for successful professional development. New insights from research should be shared with policy makers as initiatives and regulations are developed to implement policy in schools. Policy makers should also share the research they are using as a basis for their policies (Cohen et al., 2009). Jaquith (2014) stated that a productive relationship between educators and policy makers relies on regular communication between the two groups and a genuine attempt to learn by both groups. More equality of decision making is also important. This can lead to a shared understanding of both policy makers and educators. 


\section{Stakeholders Working Together for Children, Teachers, and Schools}

It is critical for educators in the fields of educational policy and professional development to work together to develop effective evidence-based practices. Two good examples of organizations that are designed to specifically examine issues in educational policy and practice are the Stanford Center for Opportunity Policy in Education and the Learning Policy Institute. The Stanford Center for Opportunity Policy in Education provides a forum for scholars to examine research, policy, and practice to develop effective schools. The Learning Policy Institute is an independent nonprofit and nonpartisan organization that was designed especially to focus on solutions that lead to the improvement of policy and practice. This is accomplished through the collaborative teamwork with those who are involved in developing and implementing educational policy (policy makers, researchers, and educators). Both organizations publish a wide variety of materials (articles, blogs, etc.) that inform the public about the different issues that face schools and their communities and hold events that bring different stakeholders together for a common cause.

Research through these organizations can provide support to various states as they develop their policies regarding teacher and student assessment, professional development, resources, and other issues. For instance, Jaquith, Mindich, Wei, and Darling-Hammond (2010) published a report regarding teacher professional learning, which described various case studies from four different states. This report provided information on how these states plan for and develop teacher learning. It also included aspects that are important for teacher professional learning.

At the local level, Coburn (2006) suggested a more prognostic view to address systemic changes that may be needed based on policy implementation. This should include the input of local policy makers, school administrators, and teachers. In the process, teachers and leadership (school and district) examine the deeper issues that can contribute to student failure in their specific situation and focus on their program needs (Taylor, Raphael, \& Au, 2011; Thessin \& Starr, 2011). In this way, leadership at different levels (school administrators and district office administrative personnel) can help "schools strategically manage external demands" (Honig \& Hatch, 2004, p. 27). Through these professional discussions, teachers and school administrators are creating a collaborative and collegial structure for implementing any new professional development plan that may determine the impact on students' learning (Guskey, 2003). The outcome is a professional development plan that is focused on fewer instructional issues while aligning to a new method of implementation, such as coaching, professional learning communities, book studies (Knight, 2009; Semadeni, 2010).

As school personnel attempt to address the needs of their students and teachers, there are other areas that should be considered. First, school is not only a place where students are learning, but it is also a place where teachers have opportunities to examine the best ways to teach their students. Thus, effective teachers are constantly changing their practices to align with their students' academic needs. Given the time and guidance, teachers can gain a deeper understanding of how their students learn (Bandura, 1977; Kragler et al., 2008; Vygotsky, 1978), and in fact, can be motivated to continue to investigate any new instructional method (Guskey, 2003). The concern is that teachers may not be given the time and support needed to determine if the new methods are effective and in fact, impact student learning. Spillane and colleagues (2002) stressed there may be a failure of new policy implementation when the new instructional methods are unclear or when the new methods do not align with the teachers.

\section{Conclusion}

Comparing these two important fields of research, educational policy and teacher professional development, revealed that both fields have some common areas of interest, but it also revealed why often mandated policies fail to achieve the full implementation of a new initiative. The literature in these two fields indicated school reform is a complicated process that takes time and effort (Guskey 
\& Yoon, 2009; Rose, 2010; Wilkinson \& Son, 2011). The focus of both is on the improvement of daily classroom instruction which would lead to increased student achievement (Darling-Hammond, 2010; Dillon et al., 2011; Guskey, 2003; Hill, 2009; Rose, 2010). The needs of individual teachers are the heart of any teacher professional development, whereas educational policy tends to focus on the school as whole rather than individual teachers. In addition, educational policy enactment in a large part depends on the interpretation and discretion of teachers (Coburn, 2006). As a result, policy decisions designed to direct classroom instruction may not necessarily bring about changes in teacher practice (Smit, 2005).

Ultimately, as seen in both fields of research, there needs to be consideration of the demands placed on teachers (Fullan, 2000; Knapp et al., 1998; Knight, 2009). It is also clear that school leadership needs to carefully review educational policies, and with teachers, develop an effective plan for implementing new policies. Without this review process, instructional decisions may not be effective and actually interfere with student achievement (Valencia \& Wixson, 2004). In addition, a review process should involve teachers in any decisions that will impact their instruction and classrooms (Allington, 2009; Kragler et al., 2008; Quick, Holtzman, \& Chaney, 2009; Semadeni, 2010).

Working together with the various stakeholders to seek input from all concerned parties creates an environment that is highly motivational and meets the needs of both the school leadership and the teachers (Friedrich \& McKinney, 2010). This will ensure educators' professional needs (i.e., beliefs, practices, and assumptions) are not absent from decisions on how to implement any educational policy (Smit, 2005).

\section{References}

Allington, R. L. (2009). Literacy policies that are needed: Thinking beyond "No Child Left Behind." In J. V. Hoffman \& Y. M. Goodman (Eds.), Changing literacies for changing time: An historical perspective on the further of reading research, public policy, and classroom practices (pp. 247-265). New York, NY: Routledge.

Bandura, A. (1977). Social learning theory. New York, NY: General Learning Press.

Bryk, A., Sebring, P., Allensworth, P., Luppescu, S., \& Easton, J. (2010). Organizing schools for improvement: Lessons from Chicago. Chicago, IL: University of Chicago Press.

Coburn, C. (2001). Collective sensemaking about reading: How teachers mediate reading policy in their professional communities. Educational Evaluation and Policy Analysis, 23, 145-170.

Coburn, C. (2006). Framing the problem of reading instruction: Using frame analysis to uncover the microprocesses of policy implementation. American Educational Research Journal, 43, 343379.

Cohen, J., McCabe, E. M., Michelli, N. M., \& Pickeral, T. (2009). School climate: Research, policy, practice, and teacher education. Teachers College Record, 111, 180-213.

Creswell, J. W. (2003). Research design: Qualitative, quantitative, and mixed methods approaches (2nd ed.). Thousand Oaks, CA: Sage.

Cummins, J. (2007). Pedagogies for the poor? Realigning reading instruction for low-income students with scientifically based reading research. Educational Researcher, 36, 564-572.

Darling-Hammond, L. (2010). America's commitment to equity will determine our future. Phi Delta Kappan, 91, 8-14.

Darling-Hammond, L., Wei, R., Andree, A., Richardson, N., \& Orphanos, S. (2009). Professional learning in the learning profession: A status report on teacher development in the United States and abroad. Dallas, TX: National Staff Development Council and The School Redesign Network at Stanford University. 
Desimone, L. M. (2011). A primer on effective professional development. Phi Delta Kappan, 92, 6871.

Dillon, D. R., O’Brien, D. G., Sato, M., \& Kelly C. M. (2011). Professional development and teacher education for reading instruction. In M. L. Kamil, P. D. Pearson, E. B. Moje, \& P. P. Afflerbach (Eds.), Handbook of reading research, Volume IV (pp. 627-660). New York, NY: Routledge.

Donnelly, A., Morgan, D., DeFord, D., Files, J., Long, S., Mills, H., . . Styslinger, M. (2005).Transformative professional development. Language Arts, 82, 336-346.

Edmondson, J. (2004). Reading policies: Ideologies and strategies for political engagement. The Reading Teacher, 57, 418-428.

Evans, L., Thornton, B., \& Usinger, J. (2012). Theoretical frameworks to guide school improvement. NASSP Bulletin, 96, 154-171.

Every Student Succeeds Act. 114 U.S.C. (2015). Retrieved from https://www.gpo.gov/fdsys/pkg/BILLS-114s1177enr/pdf/BILLS-114s1177enr.pdf

Executive Office of the President. (2013). Federal science, technology, engineering, and mathematics (STEM) education 5-year strategic plan: A report from the Committee on STEM Education National Science and Technology Council. Washington, DC: National Science and Technology Council. Retrieved from https://www.whitehouse.gov/sites/whitehouse.gov/files/ostp/Federal_STEM_Strategic_Plan.p df

Firestone, W. A., \& Mangin, M. M. (2014). Leading professional learning in districts with a student learning culture. In L. E. Martin, S. Kragler, D. J. Quatroche, \& K. L. Bauserman (Eds.), Handbook of professional development in education: Successful models and practices, preK12 (pp. 319-338). New York, NY: Guilford Press.

Friedrich, L., \& McKinney, M. (2010). Teacher inquiry for equity: Collaborating to improve teaching and learning. Language Arts, 87, 241-251.

Fullan, M. (2000). The three stories of education reform. Phi Delta Kappan, 81, 581-584.

Garet, M., Porter, A., Desimone, L., Birman, B., \& Yoon, K. (2001). What makes professional development effective? Results from a national sample of teachers. Educational Research Journal, 38, 915-945.

Glickman, C. (1990). Pretending not to know what we know. Educational Leadership, 48, 4-10.

Grady, M. P., Helbling, K. C., \& Lubeck, D. R. (2008). Teacher professionalism since A Nation at Risk. Phi Delta Kappan, 89, 603-604, 607.

Guskey, T. R. (2003). What makes professional development effective? Phi Delta Kappan, 84, 748750 .

Guskey, T. R., \& Yoon, K. S. (2009). What works in professional development? Phi Delta Kappan, 90, $495-500$.

Hargreaves, A. (1995). Development and desire: A postmodern perspective. In T. R. Guskey \& M. Huberman (Eds.), Professional development in education: New paradigms and practices (pp. 9-34). New York, NY: Teachers College Press.

Hargreaves, A. (2014). Foreword: Six sources of change in professional development. In L. E. Martin, S. Kragler, D. J. Quatroche, \& K. L. Bauserman (Eds.), Handbook of professional development in education: Successful models and practices, preK-12 (pp. x-xix). New York, NY: Guilford Press.

Hill, H. C. (2009). Fixing teacher professional development. Phi Delta Kappan, 90, 470-476. 
Hochberg, E. D., \& Desimone, L. M. (2010). Professional development in the accountability context: Building capacity to achieve standards. Educational Psychologist, 45, 89-106.

Honig, M. I. (2006). Complexity and policy implementation: Challenges and opportunities for the field. In M. I. Honig (Ed.), New directions in education policy implementation: Confronting complexity (pp. 1-23). Albany, NY: State University of New York Press.

Honig, M. I., \& Hatch, T. C. (2004). Crafting coherence: How schools strategically manage multiple, external demands. Educational Researcher, 33, 16-30.

Jacobs, J., \& Yendol-Hoppey, D. (2014). Using action research to target and generate professional learning. In L. E. Martin, S. Kragler, D. J. Quatroche, \& K. L. Bauserman (Eds.), Handbook of professional development in education: Successful models and practices, preK-12 (pp.304318). New York, NY: Guilford Press.

Jaquith, A. (2014). Changing the relationship between professional development policy and the practitioner's role. In L. E. Martin, S. Kragler, D. J. Quatroche, \& K. L. Bauserman (Eds.), Handbook of professional development in education: Successful models and practices, preK12 (pp.304-318). New York, NY: Guilford Press.

Jaquith, A., Mindich, D., Wei, R., \& Darling-Hammond, L. (2010). Teacher professional learning in the United States: Case studies of state policies and strategies (Summary Report). Stanford, CA: Stanford Center for Opportunity in Education.

Katzenmeyer, M., \& Moller, G. (2001). Awakening the sleeping giant. Thousand Oaks, CA: Corwin Press.

Knapp, M. S., Bamburg, J. D., Ferguson, M. C., \& Hill, P. T. (1998). Converging reforms and the working lives of frontline professionals in the schools. Educational Policy, 12, 397-418.

Knight, J. (2009). What can we do about teacher resistance? Phi Delta Kappan, 90, 508-513.

Knowles, M. (1970). The modern practice of adult education: Andragogy versus pedagogy. Englewood Cliffs, NJ: Prentice Hall/Cambridge.

Kragler, S., Martin, L. E., \& Kroeger, D. C. (2008). Money down the drain: Mandated professional development. Journal of School Leadership, 18, 528-550.

Krippendorff, K. (2004). Content analysis: An introduction to its methodology (2nd ed.). Thousand Oaks, CA: Sage.

Leathwood, K., Harris, A., \& Hopkins, D. (2008). Seven strong claims about successful school leadership. School Leadership and Management, 28, 27-42.

Lieberman, A., \& Miller, L. (2014). Teachers as professionals: Evolving definitions of staff development. In L. E. Martin, S. Kragler, D. J. Quatroche, \& K. L. Bauserman (Eds.), Handbook of professional development in education: Successful models and practices, preK12 (pp. 3-21). New York, NY: Guilford Press.

Long, R. (2011). Professional development and education policy: Understanding the current disconnect. Reading Today, 29, 29-30.

Long, R. (2014). Federal investments in professional development: What do 50 years of experience tell us about what it takes to make a difference. In L. E. Martin, S. Kragler, D. J. Quatroche, \& K. L. Bauserman (Eds.), Handbook of professional development in education: Successful models and practices, preK-12 (pp. 22-41). New York, NY: Guilford Press.

Marrongelle, K., Sztajn, P., \& Smith, M. (2013). Scaling up professional development in an era of common state standards. Journal of Teacher Education, 64, 202-211.

McLaughlin, M. (2006). Implementation research in education: Lessons learned, lingering questions and new opportunities. In M. I. Honig (Ed.), New directions in education policy 
implementation: Confronting complexity (pp. 209-229). New York, NY: State University of New York Press.

McMullen, P. (2006). Inertia remains the biggest impediment to change. Journal of Staff Development, 27, 72 .

Merriam, S. B. (2001). Andragogy and self-directed learning: Pillars of adult learning. New Directions for Adult and Continuing Education, 2001, 3-14.

Mezirow, J. (1994). Understanding transformation theory. Adult Education Quarterly, 44, 222-232.

Mezirow, J. (2003). Transformative learning as discourse. Journal of Transformative Education, 1, $58-63$.

Murphy, J. (2013). The architecture of school improvement. Journal of Educational Administration, $51,252-263$.

Putnam, R., \& Borko, H. (2000). What do new views of knowledge and thinking have to say about research on teacher learning. Educational Researcher, 29, 4-15.

Quick, H., Holtzman, D. J., \& Chaney, K. R. (2009). Professional development and instructional practice: Conceptions and evidence of effectiveness. Journal of Educational for Students Placed at Risk, 14, 45-71.

Ray, K. W., \& Cleaveland, L. B. (2004). About the authors: Writing workshop with our youngest writers. Portsmouth, NH: Heinemann.

Rose, M. (2010). Reform: To what end? Educational Leadership, 67, 6-11.

Rothman, R. (2012-2013). Putting the pieces in place. Educational Leadership, 70, 18-22.

Sarason, S. B. (2004). And what do you mean by learning? Portsmouth, NH: Heinemann.

Schmidt, T. (2008). Scratching the surface of Not Child Left Behind: How No Child Left Behind unfairly affects schools with significant proportions of disadvantaged students. Retrieved from ERIC database. ERIC Document 501254.

Scot, J. P., Callahan, C. M., \& Urquhart, J. (2009). Paint-by-number teachers and cookie-cutter students: The unintended effects of high-stakes testing on the educational of gifted students. Roeper Review, 31, 40-52.

Semadeni, J. (2010). When teachers drive their learning. Educational Leadership, 67, 66-69.

Shannon, P., Edmondson, J., Ortega, L., Pitcher, S., \& Robbins, C. (2009). Fifty years of federal government involvement in reading education. In J. V. Hoffman \& Y. M. Goodman (Eds.), Changing literacies for changing time: An historical perspective on the further of reading research, public policy, and classroom practices (pp. 247-265). New York, NY: Routledge.

Smit, B. (2005). Teachers, local knowledge, and policy implementation: A qualitative policy-practice inquiry, Education and Urban Society, 37, 292-306.

Snow, C., Griffin, P., \& Burns, M. (Eds.). (2005). Knowledge to support the teaching of reading. San Francisco, CA: John Wiley \& Sons.

Spillane, J. P., Reiser, B. J., \& Reimer, T. (2002). Policy implementation and cognition: Reframing and refocusing implementation research. Review of Educational Research, 72, 387-431.

Taylor, B. M., Pearson, P. D., Peterson, D. S., \& Rodriquez, M. C. (2005). The CIERA school change framework: An evidence-based approach to professional development and school reading improvement. Reading Research Quarterly, 40, 40-68.

Taylor, B. M., Raphael, T. E., \& Au, K. H. (2011). Reading and school reform. In M. L. Kamil, P. D. Pearson, E. B. Moje, \& P. P. Afflerbach (Eds.), Handbook of reading research, Volume IV (pp. 594-628). New York, NY: Routledge. 
Thessin, R. A., \& Starr, J. P. (2011). Supporting the growth of effective professional learning communities districtwide. Phi Delta Kappan, 92, 48-54.

U.S. Department of Education. (1983). A nation at risk: The imperative for educational reform. Washington, DC: U.S. Government Printing Office.

Valencia, S. W., \& Wixson, K. K. (2004). Literacy policy and policy research that makes a difference. In R. B. Ruddell \& N. J. Unrau (Eds.), Theoretical models and processes of reading (5th ed., pp. 69-92). Newark, DE: International Reading Association.

Valli, L., Croninger, R., \& Buese, D. (2012). Studying high-quality teaching in a highly charged policy environment. Teachers College Record, 111, 1-33.

Vygotsky, L. (1978). Mind in society. Cambridge MA: Harvard University Press.

Wayne, A., Yoon, K., Zhu, P., Cronen, S., \& Garet, M. (2008). Experimenting with teacher professional development: Motives and methods. Educational Researcher, 37, 469-479.

Weick, K. E., Sutcliffe, K. M., \& Obstfeld, D. (2005). Organizing and the process of sensemaking. Organization Science, 16, 409-421.

West, M., \& Peterson, P. (2003). The politics and practice of accountability. In P. Peterson \& M. West (Eds.), No Child Left Behind: The politics and practice of school accountability (pp. 1-22). Washington, DC: Brookings Institution Press.

Wilkinson, I. A. G., \& Son, H. E. (2011). A dialogic turn in research on learning and teaching to comprehend. In M. L. Kamil, P. D. Pearson, E. B. Moje, \& P. P. Afflerbach (Eds.), Handbook of reading research, Volume IV (pp. 359-387). New York, NY: Routledge Publishing.

Wolk, R. (2010). Education: The case for making it personal. Educational Leadership, 67, 16-21.

Woodside-Jiron, H., \& Gehsmann, K. (2009). Peeling back the layers of policy and school reform: Revealing the structural and social complexities within. International Journal of Disability, Development, and Education, 56, 49-72.

The Journal of Educational Research and Practice provides a forum for studies and dialogue that allows readers to better develop social change in the field of education and learning. Journal content may focus on educational issues of all ages and in all settings. It also presents peer-reviewed commentaries, book reviews, interviews of prominent individuals, and additional content. The objectives: We publish research and related content that examines current relevant educational issues and processes aimed at presenting readers with knowledge and showing how that knowledge can be used to impact social change in educational or learning environments. Additional content provides an opportunity for scholarly and professional dialogue regarding that content's usefulness in expanding the body of scholarly knowledge and increasing readers' effectiveness as educators. The journal also focuses on facilitating the activities of both researcher-practitioners and practitioner-researchers, providing optimal opportunities for interdisciplinary and collaborative thought through blogging and other communications.

Walden University Publishing: http://www.publishing.waldenu.edu 